\title{
A monografia de um tempo português ${ }^{1}$
}

\section{Francisco Carlos Palomanes Martinho ${ }^{2}$}

MENESES, Filipe Ribeiro de. Salazar: uma biografia política. 3. ed. Lisboa: D. Quixote, 2010.

Em 2007, a RTP (Rádio e Televisão de Portugal) promoveu um concurso intitulado "Os Grandes Portugueses", a fim de escolher o nome mais representativo de sua história. Concorrendo com personagens da grandeza de Camões, Vasco da Gama e Fernando Pessoa, entre outros, o ditador do Estado Novo Oliveira Salazar saiu vencedor com pouco mais de $40 \%$ dos votos.

A despeito de sua "representatividade", Salazar ainda não havia sido objeto de um trabalho acadêmico rigoroso. A lacuna foi, entretanto, preenchida com a chegada do estudo de Filipe Ribeiro de Meneses.

\footnotetext{
${ }^{1}$ Resenha recebida e aprovada para publicação em março de 2011.

${ }^{2}$ Professor do Departamento de História da USP e pesquisador do CNPq.
}

Publicada originalmente para um público não português, a obra consiste em um aprofundado estudo que integra as vidas pessoal e pública de um professor de Economia, católico e solteirão que incorporou para si a tarefa de fazer os portugueses viverem habitualmente, conforme disse ao pensador católico francês Henri Massis. O viver projetado por Salazar consistia em uma ditadura alheia às aventuras revolucionárias dos fascismos clássicos alemão e italiano ou mesmo do militarismo de pendor cesarista de seu vizinho espanhol. Filipe de Meneses consegue perceber os importantes traços de continuidade entre o filho de Santa Comba Dão, o ex-seminarista que, quando ingressou como professor da Universidade de Coimbra, apresentou uma tese defensora da pequena propriedade agrícola, e o chefe de governo 
que nunca deixou de afirmar a superioridade do campo sobre a cidade, esta lugar dos "vícios dissolventes" da tradição portuguesa.

Filho caçula de uma família pobre, com quatro irmãs, Salazar estudou no seminário de Viseu. Destacado aluno, ingressou na Universidade de Coimbra, onde se formou em 1911. Dessa época o livro aponta para relações de amizade que permaneceram ao longo de toda a vida do futuro ditador, como Mário de Figueiredo e Manuel Gonçalves Cerejeira, o futuro patriarca da Igreja Católica em Portugal.

Militante na Universidade do Centro Católico, Salazar foi sempre fiel aos valores legados de um pensamento social católico que tem na Encíclica Rerum Novarum a sua principal referência. Foi, por isso, um forte opositor tanto do liberalismo e da democracia parlamentar quanto do comunismo e dos movimentos socialistas. Seu projeto político-ideológico sempre foi a constituição, em Portugal, de um regime centralizado e fiel às tradições que, a seu ver, marcam a formação portuguesa: um catolicismo marcado por uma forte vocação messiânica, cruzadista e expansionista.

O livro é rico em exemplos que demonstram a capacidade de Salazar em mediar com interesses conflitantes no seio do regime autoritário. Como ministro das Finanças, arquitetou a transição de uma ditadura militar para uma ditadura civil e corporativa sob o seu controle. Mantendo sempre um militar na presidência, não deixou de acalentar as esperanças dos monarquistas ávidos pela mudança do regime. $\mathrm{Na}$ montagem do governo, incorporou à sua máquina republicanos conservadores, católicos e até mesmo militantes do integralismo lusitano, a versão portuguesa do fascismo. Nesse caso, sobretudo, trouxe para a esfera da administração jovens universitários que, em breve tempo, teriam espaço e importância crescente no regime, como Pedro Teotónio Pereira e Marcello Caetano. Ciente do complexo leque de alianças que o apoiava, Salazar dissolveu o Centro Católico e criou um partido único, um "não partido", de acordo com suas palavras, a União Nacional. A constituição aprovada em 1933, corporativa e autoritária, manteve, entretanto, um verniz liberal quer na permanência de uma Câmara, aliás duas, se contarmos a Câmara Corporativa, quer na eleição, por sufrágio universal, do presidente da República.

Apesar da preocupação em analisar a vida privada de Salazar, o livro cresce nos momentos em que relata as crises vividas pelo Estado Novo português e 
as medidas tomadas por Salazar. Como durante a Segunda Guerra Mundial, quando a incerteza a respeito da continuidade do Estado Novo era motivo de euforia para seus opositores e preocupação para seus adeptos. Naquela conjuntura, Salazar adotou uma política de neutralidade, ao mesmo tempo em que envidava todos os esforços para impedir que a vizinha Espanha aderisse ao conflito. Neutralidade que, entretanto, não impediu a cessão para os Aliados da Base Militar dos Açores. A estratégia do ditador garantiu a entrada imediata de Portugal na OTAN (Organização do Tratado do Atlântico Norte) e a continuidade do regime no pós-guerra. No final da década de 1950, novo período de instabilidade, com a campanha à presidência da República de Humberto Delgado. Uma campanha de massas, "à americana", estranha e incômoda ao regime. Também na década de 1950 , Salazar se viu obrigado a mediar as disputas entre setores "conservadores", sob a liderança de Santos Costa, e "modernos", capitaneados por Marcello Caetano.

Mas foi na década de 1960 que o "caldo" começou de fato a entornar. Os estudantes saíam às ruas e misturavam reivindicações tanto acadêmicas como políticas. Nas relações diplomáticas, a Europa tornava-se um parceiro cada vez mais constante, relativizando a natureza atlântica, tão cara aos adeptos do Estado Novo. Mas, sobretudo na África, os movimentos de libertação começavam, em 1961, a defender a ruptura com a antiga metrópole. Apesar de tentativas de mediação por parte das diplomacias americana, brasileira, espanhola ou mesmo do Vaticano, Salazar recusava-se a ceder ou mesmo negociar. "Estamos cada vez mais orgulhosamente sós", foi o que disse em resposta às insistentes pressões internacionais. Em 1968, ano em que sofre o acidente caseiro que o impossibilita de continuar a governar, a guerra colonial já não tinha retorno. Com ela, o país vê seus braços partirem. Para o ultramar alguns. Para a França ou para o Brasil outros. Que se a participar de um conflito que não compreendiam e não aceitavam, pelo menos não a ponto de se alistarem na tropa. Um paradoxo: o ditador recusava-se a mover qualquer palha em um país que já não vivia mais "habitualmente". Essa última década de vida política de Salazar foi também a que sofreu mais questionamentos, inclusive internos. A recusa de ceder no caso africano reproduzia-se também na relação com o poder. Cedê-lo pressupunha a possibilidade de ser criticado por sucessores. Nesse caso, a aparência franciscana podia tam- 
bém ser confundida com arrogância e alheamento para com os outros.

Disse Gramsci que a trajetória de um homem pode ser a monografia de seu tempo. O livro de Filipe Ribeiro de Meneses, sólido, erudito, bem-documentado, é uma referência obrigatória para o entendimento da recente história portuguesa. 